\title{
Spatial patterns in the population structure of the whelk Stramonita haemastoma (Linnaeus, 1766) (Gastropoda: Muricidae) in the Canarian Archipelago (eastern Atlantic)
}

\author{
RUBÉN RAMÍREZ ${ }^{1}$, FERNANDO TUYA ${ }^{1,2}$ and RICARDO J. HAROUN ${ }^{1}$ \\ ${ }^{1}$ Centro de Investigación en Biodiversidad y Gestión Ambiental (BIOGES), Faculty of Marine Sciences, Campus de Tafira \\ s/n, University of Las Palmas de Gran Canaria, 35017 Las Palmas de Gran Canaria, Canary Islands, Spain. \\ E-mail: rramirezcanada@yahoo.es \\ ${ }^{2}$ Centre for Marine Ecosystems Research, Edith Cowan University, Joondalup Drive, Joondalup, WA 6027, Australia
}

\begin{abstract}
SUMMARY: The goal of this study was to determine the consistency of the vertical distribution patterns of the predatory whelk, Stramonita haemastoma, in the rocky intertidal zone of the Canarian Archipelago (eastern Atlantic) across a hierarchy of five orders of magnitude of horizontal spatial variability (from tens of $m$ to hundreds of $\mathrm{km}$ ). In general, this species showed a consistent vertical zonation pattern across islands, with the majority of the specimens $(74.65 \%)$ found in the mid intertidal zone. This result most likely reflects the whelk's preference for a habitat with a large amount of potential prey but minimal stress induced by swells and desiccation. The mean abundance $\left(0\right.$ to $1.73 \pm 0.40$ ind $\mathrm{m}^{-2}$, mean $\left.\pm \mathrm{SE}\right)$ and size structure (7 to $45 \mathrm{~mm}$ in shell length) of $S$. haemastoma in the Canarian Archipelago was considerably lower compared to those from continental areas in the Atlantic Ocean, which suggests that there are some differences between these populations. Natural mechanisms (e.g. isolation or poor recruitment events) and human perturbations (e.g. exploitation of intertidal resources) might influence the spatial distribution patterns.
\end{abstract}

Keywords: Stramonita haemastoma, predators, spatial distribution, rocky coasts, Canary Islands.

RESUMEN: Patrones espaciales en la estructura poblacional del caracol Stramonita haemastoma (Linnaeus, i 766) (Gastropoda: Muricidae) en el Archipiélago Canario (Atlántico oriental). - El objetivo de este estudio fue determinar la consistencia de los patrones de distribución vertical del caracol predador, Stramonita haemastoma, en el intermareal rocoso del archipiélago Canario (Atlántico oriental), a través de un modelo jerárquico que incluyó cinco órdenes de magnitud de variabilidad espacial horizontal (desde decenas de $\mathrm{m}$ hasta centenares de $\mathrm{km}$ ). En general, esta especie mostró un patrón de zonación vertical consistente entre islas, con la mayoría de los ejemplares (74.65\%) presentes en la zona intermareal media. Este resultado probablemente refleja una preferencia hacia un hábitat con mayor disponibilidad de presas, pero minimizando el estrés inducido por la exposición al oleaje y la desecación. El rango de abundancias $(0$ a 1.73 ind $\mathrm{m}^{-2}$, media $\pm \mathrm{SE}$ ) y la estructura de tallas (7-45 mm en longitud de concha) fueron notablemente bajos en relación a los observados en la costa continental del Atlántico, sugiriendo diferencias entre dichas poblaciones. Procesos naturales (e.g. aislamiento o eventos de escaso reclutamiento) y perturbaciones humanas (e.g. explotación de los recursos intermareales) pueden haber influido sobre estos patrones de distribución espacial.

Palabras clave: Stramonita haemastoma, predadores, distribución espacial, costas rocosas, Islas Canarias.

\section{INTRODUCTION}

Rocky coasts are heterogeneous habitats in which different floral and faunal assemblages re- spond to sharp environmental gradients. Physical, ecological (including human-induced disturbances) and evolutionary-determined factors affect the distribution patterns of these assemblages at different 
spatial and temporal scales (Benedetti-Cecchi et al., 2000; Moreno, 2001; Thompson et al., 2002; Fraschetti et al., 2005). The analysis of this variability is a key requisite for understanding the importance of different processes, and for constructing (and generalizing) predictive models of the ecological patterns of intertidal assemblages (Levin, 1992; Underwood and Chapman, 1996; Benedetti-Cecchi, 2001).

Predatory prosobranch molluscs, such as the globally-distributed whelk Stramonita haemastoma (Linnaeus 1766), have been widely recognized as key organisms that determine the structure and organization of intertidal communities (Connell, 1961; Menge, 1978; Edwards et al., 1982; Liu et al., 1991; Rilov et al., 2001). Spatio-temporal variability in the population structure of this species has been attributed to differences in abiotic processes, such as habitat structure and the degree of wave exposure (e.g. Richardson and Brown, 1990; Rilov et al., 2001, 2004; Brown et al., 2004). Similarly, limited prey availability, in terms of abundance and biomass, has been suggested to be a possible mechanism behind the low abundances and growth rates of these intertidal carnivores on some coasts (Mckillup and Butler, 1983; Burrows and Hughes, 1990; Mckillup and Mckillup, 1997; Ota and Tokeshi, 2000).

The goal of this study was to test the consistency of the vertical distribution patterns of $S$. haemastoma on the rocky coasts of the Canary Archipelago (eastern Atlantic) by identifying patterns of spatial variability over scales from tens of $m$ to hundreds of $\mathrm{km}$. In addition, bibliographic data was used to determine whether there are differences in the population structure of this species (abundance and size structure) between insular systems and continental areas of the Atlantic Ocean.

\section{MATERIAL AND METHODS}

\section{Study area and sampling}

The study was carried out on the coasts of the seven islands that constitute the Canarian Archipelago (eastern Atlantic) and in the group of small islets that constitutes the Chinijo Archipelago, during March 2003 (Fig. 1). These intertidal systems are rocky platforms of volcanic origin (mainly basalts), with a width between 30 and $130 \mathrm{~m}$. Differences in age between the eastern ('old' islands) and the western islands ('young' islands) (Carracedo, 2001) have led to dissimilarities in the mean length of these platforms (eastern islands $=64.66 \pm 6.32 \mathrm{~m}$, western islands $=45.16 \pm 8.51 \mathrm{~m}$; mean $\pm \mathrm{SE}$ ). In general, three zones can be recognized in the rocky intertidal zone of the Canary Islands according to classical zonation schemes (Stephenson and Stephenson, 1949; Lawson and Norton, 1971): the high, mid, and low intertidal zones. The high zone is characterized by a cyanobacterial film of blue-green bacteria, the mid zone is dominated by the cirriped barnacle

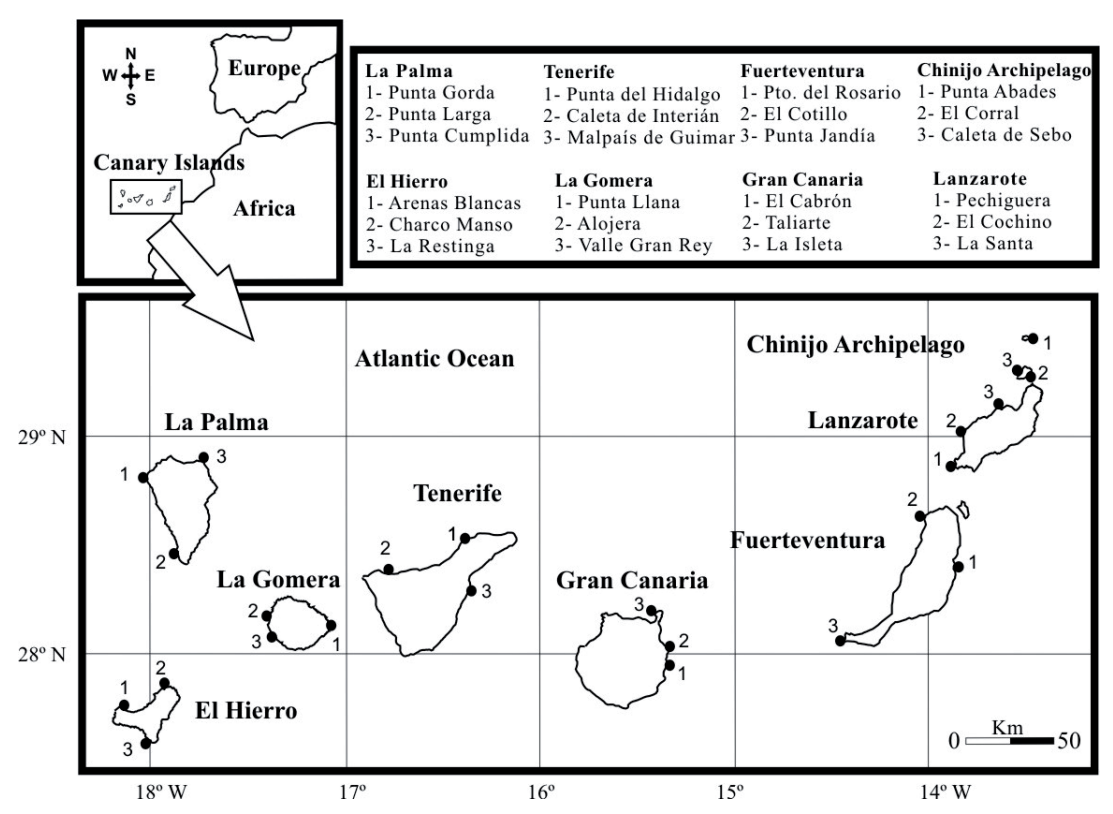

FIG. 1. - Map of the sampling localities at each island throughout the Canarian Archipelago (eastern Atlantic). 
Chthamalus stellatus, and the lower zone is covered by a conspicuous canopy of turf-forming algae.

Three localities 1 to $50 \mathrm{~km}$ apart were randomly chosen at each island. In addition, 3 randomly-selected sites, tens of $\mathrm{m}$ apart, were selected within each intertidal zone at each locality. We haphazardly placed ten $50 \times 50 \mathrm{~cm}\left(0.25 \mathrm{~m}^{2}\right)$ quadrats several meters apart on each of the 3 sites within each intertidal zone and locality. We counted and measured (shell length to the nearest $\mathrm{mm}$ - SL) all the S. haemastoma within each quadrat. As a result, we adopted a hierarchical design that spans five orders of magnitude of horizontal spatial variability, and incorporates islands $\left(10^{4}-10^{5} \mathrm{~m}\right.$ apart), localities $\left(10^{3}-10^{4} \mathrm{~m}\right.$ apart $)$, sites $\left(10^{1}-10^{2} \mathrm{~m}\right.$ apart) and quadrats $\left(10^{0}-10^{1} \mathrm{~m}\right.$ apart).

\section{Statistical analysis}

We tested the significance of the differences in the mean abundances between the three intertidal zones across the set of spatial scales by means of a mixed, partially nested, ANOVA model (Underwood, 1997). The model incorporated the following factors: (1) 'Island' (fixed factor with eight levels corresponding to the seven islands plus the Chinijo Archipelago), (2) 'Zone' (fixed factor with three levels corresponding to the high, mid and low intertidal zones, and orthogonal to the previous factor), (3) 'Locality' (random factor nested within 'Island' with three levels) and (4) 'Site' (random factor nested within 'Locality', 'Island', and 'Zone', with three levels). Due to the high heterogeneity of variances, which persisted after data transformation (Cochran's test, $\mathrm{P}<0.01$ ), we considered a significance level of $\alpha=0.01$ instead of $\alpha=0.05$ to avoid an increase in the Type I error; ANOVA is robust to heterogeneity of variances, particularly for large balanced studies (Underwood, 1997). When the ANOVA detected significant differences for 'Island' and/or 'Zone', either as an interaction or as a main effect, further analyses were performed by using the SNK a-posteriori multiple comparison tests to resolve differences. To estimate the contribution of each horizontal spatial scale (island, locality, site and quadrat) to the total variability of each intertidal zone, we calculated the corresponding variance components, and subsequently the percentage of contribution of each spatial scale. We tested for differences in mean sizes (SL) among islands and intertidal zones using 95\% confidence intervals (Underwood, 1997; MartínezGonzález et al., 2001).
TABLE 1. - Results of the ANOVA testing for differences between islands (fixed), intertidal zones (fixed and orthogonal), localities (random and nested within islands) and sites (random and nested within islands, zones and localities) in the mean abundances of Stramonita haemastoma across the Canarian Archipelago.

\begin{tabular}{lrrl}
\hline Source of variation & df & MS & F \\
\hline Island = Is & 7 & 15.47 & $0.69(\mathrm{~ns})$ \\
Zone $=$ Z & 2 & 139.82 & $7.87^{*}$ \\
Locality (Is) = Lo (Is) & 16 & 22.52 & $3.66^{* *}$ \\
Site (Lo (Is) x Z) & 144 & 6.14 & $2.49^{* *}$ \\
Is x Z (Is) & 14 & 20.62 & 1.16 (ns) \\
Z x Lo (Is) & 32 & 17.77 & $2.89^{* *}$ \\
Residual & 1944 & 2.47 & \\
Total & 2159 & & \\
\hline
\end{tabular}

*: $P<0.01$; **: $P<0.0001$; ns: non-significant; df: degrees of freedom; MS: Mean Squares; F: Fisher's F

\section{RESULTS}

We observed 213 individuals of the whelk, S. haemastoma, during the study, with a mean abundance (per locality) of $0.39 \pm 0.04$ ind $\mathrm{m}^{-2}$ (mean $\pm \mathrm{SE}$ ). The islands of El Hierro, Chinijo Archipelago and La Gomera showed the highest abundances per island $\left(0.79 \pm 0.15,0.58 \pm 0.14\right.$, and $0.56 \pm 0.12$ ind $\mathrm{m}^{-2}$ respectively), whereas Fuerteventura showed the lowest mean abundance $\left(0.03 \pm 0.02\right.$ ind $\left.\mathrm{m}^{-2}\right)$. However, as a result of the large variability among localities (Table $1)$, significant differences among islands were not observed ('Islands' as main effect, $P>0.05$, Table 1 ).

Abundance patterns of $S$. haemastoma in each intertidal zone varied among localities (Zone x Locality (Island), $\mathrm{P}<0.0001$, Table 1 ). In contrast, the zoning pattern was consistent among islands (Island $\mathrm{x}$ Zone, $P>0.3$, Table 1), although some inconsistencies were observed in some islands (e.g. Tenerife and Gran Canaria showed greater abundances in the lower intertidal zone, Fig. 2). Generally, the greater abundances were observed in the mid intertidal zone (SNK, $\mathrm{P}<0.01$; Table 2), where 159 individuals (74.65\%) were found (Fig. 2).

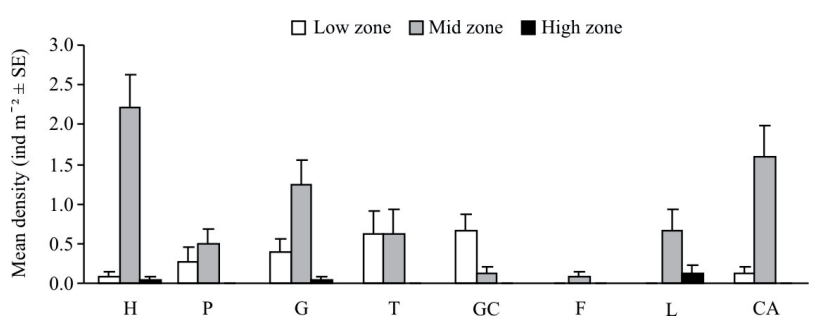

FIG. 2. - Mean densities of Stramonita haemastoma in each intertidal zone across the Canarian Archipelago. H: El Hierro, P: La Palma, G: La Gomera, T: Tenerife, GC: Gran Canaria, F: Fuerteventura, L: Lanzarote, CA: Chinijo Archipelago. 
TABLE 2. - Summary of results of pair-wise comparisons of the abundance of Stramonita haemastoma between the three intertidal zones at the 24 localities. The numbers and percentages indicate the number of localities with a significant result $(\mathrm{P}<0.05)$.

\begin{tabular}{lc}
\hline Comparisons & Number of localities $(\%)$ \\
\hline $\mathrm{LI}>$ MI & $4(20 \%)$ \\
$\mathrm{LI}>\mathrm{HI}$ & $13(65 \%)$ \\
$\mathrm{LI}=\mathrm{MI}$ & $4(20 \%)$ \\
$\mathrm{MI}>\mathrm{LI}$ & $14(70 \%)$ \\
$\mathrm{MI}>\mathrm{HI}$ & $18(90 \%)$ \\
$\mathrm{HI}=\mathrm{LI}$ & $4(20 \%)$ \\
$\mathrm{HI}>\mathrm{MI}$ & $2(10 \%)$ \\
$\mathrm{HI}>\mathrm{LI}$ & $3(15 \%)$ \\
\hline
\end{tabular}

LI: Low intertidal; MI: Mid intertidal; HI: High intertidal.

TABLE 3. - Analysis of the variance components for each intertidal zone. The contribution of each factor $\left(\omega^{2}\right)$ is presented as a percentage $(\%)$.

\begin{tabular}{|c|c|c|c|c|c|c|}
\hline & Source of variation & SS & df & MS & $\mathrm{vc}$ & $\omega^{2}$ \\
\hline \multirow[t]{5}{*}{ Low } & Island & 44.6 & 7 & 6.37 & 0 & 0 \\
\hline & Locality & 115.91 & 16 & 7.24 & 0.09 & 4.28 \\
\hline & Site & 210.13 & 48 & 4.37 & 0.24 & 11.14 \\
\hline & Residual & 1224 & 648 & 1.88 & 1.88 & 84.58 \\
\hline & Total & 1594.64 & 719 & & & \\
\hline \multicolumn{6}{|c|}{ Mid } & \\
\hline & Island & 351 & 7 & 50.15 & 0 & 0 \\
\hline & Locality & 809.2 & 16 & 50.57 & 1.22 & 16.45 \\
\hline & Site & 663.4 & 48 & 13.82 & 0.844 & 11.33 \\
\hline & Residual & 3486.4 & 648 & 5.38 & 5380 & 72.22 \\
\hline & Total & 5310.2 & 719 & & & \\
\hline \multicolumn{7}{|c|}{ High } \\
\hline & Island & 1.4 & 7 & 0.2 & 0 & 0 \\
\hline & Locality & 3.91 & 16 & 0.24 & $\approx 0$ & 0 \\
\hline & Site & 11.73 & 48 & 0.24 & 0.0098 & 6.35 \\
\hline & Residual & 94.4 & 648 & 0.14 & 0.14 & 93.65 \\
\hline & Total & 111.44 & 719 & & & \\
\hline
\end{tabular}

SS: sums of squares; df: degrees of freedom; MS: mean squares; vc: variance components; $\omega^{2}$ : contribution of effects.

Differences among quadrats at the lowest spatial scale accumulated most of the total variance in our survey ( $>72 \%$, Table 3$)$, which evidences the important role played by small-scale spatial variability in the distribution patterns of this species. We also detected high variability from site to site within islands, zones and localities (Sites (Island $\mathrm{x}$ Zone $\mathrm{x}$ Locality), $P<0.01$, Table 1$)$. In fact, this factor explained $11.14 \%, 11.13 \%$ and $6.35 \%$ of the total variability for the low, mid and high intertidal zones respectively (Table 3).

The mean size for the overall study was $21.88 \pm$ $0.40 \mathrm{~mm}$ SL (mean $\pm \mathrm{SE}$ ) and ranged between 7 and $45 \mathrm{~mm}$ SL. We obtained a unimodal and symmetric size-frequency distribution, with the majority of individuals $(>80 \%)$ in the intermediate size ranges (16 to $30 \mathrm{~mm}$ SL, Fig. 3). Table 4 shows the mean sizes per island, as well as the mean sizes in each intertidal zone, for the entire survey. In general, the

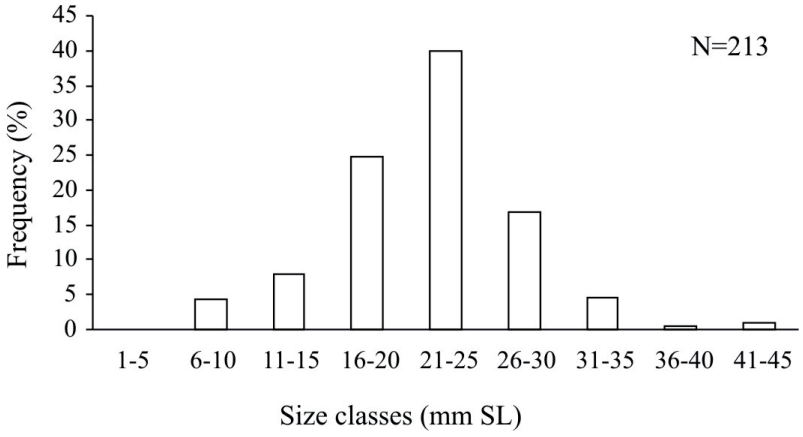

FIG. 3. - Size-frequency distribution of Stramonita haemastoma for the entire study area.

TABLE 4. - Mean sizes ( $\mathrm{mm} \mathrm{SL} \pm \mathrm{SE}$ ) of Stramonita haemastoma at each island and in each intertidal zone (data pooled across islands). Significant differences in sizes, detected by $95 \%$ confidence intervals, are indicated as a footnote.

\begin{tabular}{lccc}
\hline Island & $\begin{array}{c}\text { Mean size } \\
(\mathrm{mm} \pm \mathrm{SE})\end{array}$ & $\begin{array}{c}\text { Intertidal } \\
\text { zone }\end{array}$ & $\begin{array}{c}\text { Mean size } \\
(\mathrm{mm} \pm \mathrm{SE})\end{array}$ \\
\hline Chinijo Archipelago = CA & $22.54 \pm 0.99$ & & \\
Lanzarote $=\mathrm{L}$ & $17.61 \pm 1.71$ & Low zone & $21.33 \pm 0.78$ \\
Fuerteventura = F & $30.00 \pm 3.00$ & Mid zone & $22.27 \pm 0.46$ \\
Gran Canaria $=\mathrm{GC}$ & $24.50 \pm 1.56$ & High zone & $14.80 \pm 4.50$ \\
Tenerife $=\mathrm{T}$ & $22.21 \pm 0.92$ & & \\
La Gomera $=\mathrm{G}$ & $24.89 \pm 0.61$ & & \\
La Palma $=\mathrm{P}$ & $16.88 \pm 1.15$ & & \\
El Hierro $=\mathrm{H}$ & $20.91 \pm 0.69$ & & \\
Total study & $21.88 \pm 0.40$ & & \\
& & & \\
Significant differences $: \mathrm{G}>\mathrm{L}, \mathrm{P}, \mathrm{H}$ &
\end{tabular}

mean sizes were similar among islands, though some minor differences were observed (Table 4).

At oceanic scales, $S$. haemastoma can be found with densities from a few ind $\mathrm{m}^{-2}$ (this study) to
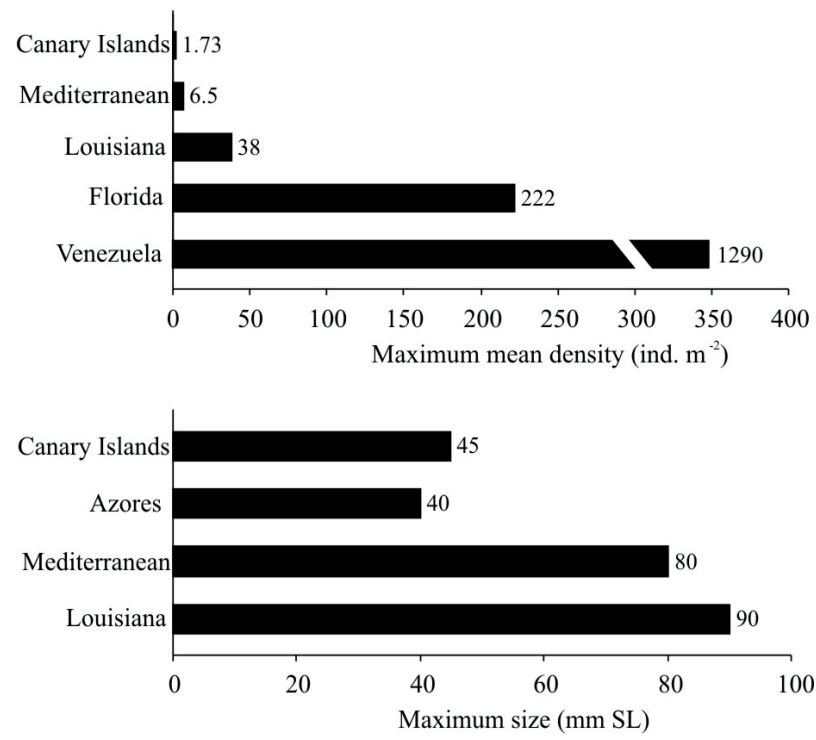

FIG. 4. - Ranges of mean abundances and sizes for Stramonita haemastoma in different coastal areas in Atlantic Ocean waters (northern hemisphere). Data sources: Florida and Venezuela (Butler, 1985), Gulf of Mexico (Brown and Richardson, 1987), Azores (Spence et al., 1990), Mediterranean (Rilov et al., 2001), Canary Islands (this study). 
densities up to hundreds, and sometimes $>1000$ ind $\mathrm{m}^{-2}$ (e.g. Venezuela, Fig. 4). Similarly, its size range can vary considerably, from 40 to $45 \mathrm{~mm}$ SL to $>80$ mm SL (Fig. 4). It stands out that low values of both density and size were generally observed in insular systems (i.e. this study and the Azores), in contrast to continental areas, where mean values were considerably larger (Fig. 4).

\section{DISCUSSION}

This study shows that the predatory whelk, S. haemastoma, usually has a regular vertical distribution pattern in the rocky intertidal zone of the Canary Islands, with higher densities in the mid compared to the low intertidal zones, and an almost complete absence of individuals in the high intertidal zone. This probably reflects the whelk's preference for a habitat with a large amount of potential prey but minimal stress induced by wave exposure and desiccation. Stramonita haemastoma, like many predatory whelks, inhabits environments rich in potential food (Moran, 1985; Rilov et al., 2001, 2004). It has a broad diet (Butler, 1985; Rilov et al., 2002), that includes barnacles, limpets, top-shell snails and periwinkles on the Canary rocky coasts (R. Ramírez pers. obs.), which are especially abundant in the mid intertidal compared with the low intertidal zone (Navarro et al., 2005; Ramírez et al., 2005). Food availability, however, is not always an adequate predictor for whelk densities in littoral zones (Rilov et al., 2001), since other factors, particularly physical conditions (e.g. wave exposure or desiccation), may also affect its distribution patterns (Moran, 1985; Menge et al., 1994; Rilov et al., 2005). A way of minimizing both the risk of wave-induced dislodgment and desiccation stress is to hide inside shelters (Menge, 1978; Moran, 1985; Richardson and Brown, 1990; Rilov et al., 2005). Displacements caused by waves are probably common in the Canary Islands, since the coasts of the archipelago are exposed directly to oceanic swells from all directions, although waves with a northern component dominate in frequency. This fact, coupled with a considerable tidal amplitude (up to $3 \mathrm{~m}$ ), results in almost constant daily exposure to strong wave action and desiccation. Therefore, the presence of shelters (e.g. crevices and holes), which are more common in the mid intertidal zone (Ramírez et al., 2008), seems to have a particular influence on the vertical distribution pattern of S. haemastoma in the Canary Islands.
Our study has confirmed that variability at small spatial scales $(1-10 \mathrm{~m})$ is a general feature of benthic populations inhabiting the rocky intertidal zone (reviewed by Fraschetti et al., 2005). The abundance of $S$. haemastoma was extremely variable at small-scales, mainly between quadrats several meters apart. This patchy pattern is consistent with observations of this species from the Mediterranean (Rilov et al., 2001) and with other intertidal molluscs from the study area (Navarro et al., 2005; Ramírez et al., 2005). This pattern is possibly related to the predatory behaviour of S. haemastoma, which can feed in groups (Brown and Alexander, 1994). Although group feeding does not seem to lower handling time, or increase per capita feeding rates, it could facilitate prey location, or could be beneficial for feeding on large preys (Brown and Alexander, 1994). Since preys are not large or very numerous in the archipelago (see below), detecting the scent of injured preys, or conspecific feeding, are potential factors that influence the distribution pattern of S. haemastoma (sensu Brown and Alexander, 1994).

The mean abundance and size structure of $S$. haemastoma in the Canarian Archipelago was considerably lower compared to continental areas in the Atlantic Ocean. For example, abundances were up to three orders of magnitude higher on the coasts of Venezuela (Butler, 1985; Fig. 4). Similarly, the population structure was dominated by small-sized individuals, consistent with observations from the nearby Azores Archipelago (Spence et al., 1990; Fig. 4). These results reflect important differences between populations inhabiting oceanic archipelagos in the eastern Atlantic and continental areas. Organisms living on islands are constrained by the isolation and fragmentation of their populations (McArthur and Wilson, 1967), while several paleoclimatic and human disturbances (reviewed by Brown and Lomolino, 2000) can also limit patterns of dispersal, growth and survival of these populations (Alexander and Roughgarden, 1996). In addition, poor recruitment events have been highlighted as a potential mechanism that explains the low abundances of intertidal macro-invertebrates found in these oceanic archipelagos (Hawkins et al., 2000). It is worth noting, moreover, that certain potential preys of $S$. haematoma are absent in the study area, or are naturally more abundant in continental areas, compared to insular systems in the eastern Atlantic (Nuñez, 1995; Hawkins et al., 2000). 
Alternatively, human-induced perturbations may have accentuated the low abundances and sizes of S. haemastoma in the Canary Islands and adjacent archipelagos (Azores and Madeira). First, intertidal resources have been extensively exploited since prehistoric times (Hawkins et al., 2000; Moro and Herrera, 2000; Batista, 2001; Cabrera, 2001), particularly species that constitute a potential prey for S. haemastoma, such as limpets and top-shell snails, and some species have been driven near to extinction (e.g. Patella candei), and reduced to small populations (Nuñez et al., 2003, Navarro et al., 2005, Ramírez et al., 2005; Ramírez et al., 2008). The greater abundances of $S$. haemastoma in the lower, compared to the mid intertidal zone at Gran Canaria and Tenerife (the two most populated islands), could be the result of the extremely low densities of potential preys that are routinely caught for human consumption, such as limpets (Navarro et al., 2005). It is possible that $S$. haemastoma has therefore been 'forced' to move down-shore, facing a higher risk of wave-induced dislodgement, but probably finding larger amounts of suitable preys. Second, the socalled 'imposex' effect has been recently detected for $S$. haematoma from this area (R. Ramírez pers. obs.). This phenomenon affects the recruitment of many species, especially molluscs, and causes a notable reduction in their physiological performance, and even local extinctions (Bryan et al, 1986; Evans et al, 1996; Rilov et al., 2000). Although sterilization of $S$. haemastoma females is not widely extended in the Archipelago, this is occurring in areas that are greatly affected by TBT, such as industrial ports and their proximities (R. Ramírez pers. obs.).

In summary, our results indicate that the distribution, abundance and size structure patterns of $S$. haemastoma in the Canary Islands most likely respond to several factors reported to influence this species in other geographic areas (e.g. food, availability of shelter, etc.) in conjunction with the specific characteristics of oceanic systems. Human-induced perturbations (e.g. harvesting, pollution, etc.) may also affect the populations of this whelk. More specific studies are necessary to disentangle the relative role of each of these processes.

\section{ACKNOWLEDGEMENTS}

We are grateful to all the volunteers that helped in collecting the data, especially Rodolfo Jaraiz, Sandra
Prieto, Patricia De la Fuente and Adrian Abelardo. We thank Dr. Pablo Sánchez-Jerez for his help with the data analysis and Dr. Stuart Jenkins for his revision and comments. This work was supported by the Spanish "Ministerio de Medio Ambiente" in the framework of the project "Canarias, por una Costa Viva" (www.canariasporunacostaviva.org). Two anonymous reviewers provided helpful comments on a previous draft.

\section{REFERENCES}

Alexander, S.E. and J. Roughgarden. - 1996. Larval transport and population dynamics of intertidal barnacles: a coupled benthic/ oceanic model. Ecol. Monogr., 66: 259-275.

Batista, C. - 2001. El marisqueo en la prehistoria de Gran Canaria. Vector plus, 18: 67-76.

Benedetti-Cecchi, L., F. Bulleri and F. Cinelli. - 2000. The interplay of physical and biological factors in maintaining mid-shore and low-shore assemblages on rocky coasts in the north-west Mediterranean. Oecologia, 123: 406-417.

Benedetti-Cecchi, L. - 2001. Variability in abundance of algae and invertebrates at different spatial scales on rocky sea shores. Mar. Ecol. Prog. Ser., 215: 79-92.

Brown, J.H. and J.E. Alexander Jr. - 1994. Group foraging in a marine gastropod predator: benefits and costs to individuals. Mar. Ecol. Prog. Ser., 112: 97-105.

Brown, J.H. and M.V. Lomolino. - 2000. Concluding remarks: historical perspective and the future of island biogeography theory. Glob. Ecol. Biog., 9: 87-92.

Brown, K.M. and T.D. Richardson. - 1987. Foraging ecology of the southern oyster drill Thais haemastoma (Gray): constraints on prey choice. J. Exp. Mar. Biol. Ecol., 114: 123-141.

Brown, K.M., M. Mcdonough and T.D. Richardson. - 2004. Intraspecific life history variation in the southern oyster drill, Stramonita haemastoma: patterns and causes. J. Shellfish Res., 23: 149-155.

Bryan, G.W., P.E. Gibbs, L.G. Hummerstone and R.G. Burt. - 1986. The decline of the gastropod Nucella lapillus around south-west England: evidence for the effect of tributyltin from the antifouling paints. J. Mar. Biol. Ass. U. K., 66: 611-640.

Burrows, M.T. and R.N. Hughes. - 1990. Variation in growth and consumption among individuals and populations of dogwhelks, Nucella lapillus: a link between foraging behaviour and fitness. J. Anim. Ecol., 59: 723-742.

Butler, P.A. - 1985. Synoptic review of the literature on the southern oyster drill Thais haemastoma floridana. NOAA Tech. Rep. NMFS, 35: 1-9.

Cabrera, J.C. - 2001. Poblamiento e impacto aborigen. In: J.M. Fernández-Palacios and J. Martín (eds.), Naturaleza de las Islas Canarias. Ecología y conservación, pp. 241-245. Turquesa, Santa Cruz de Tenerife.

Carracedo, J.C. - 2001. Volcanismo reciente y riesgo volcánico. In: J.M. Fernández-Palacios and J. Martín (eds.), Naturaleza de las Islas Canarias. Ecología y conservación, pp. 65-76. Turquesa, Santa Cruz de Tenerife.

Connell, J.H. - 1961. Effects of competition, predation by Thais lapillus, and other factors on natural populations of the barnacle Balanus balanoides. Ecol. Monogr., 31: 61-104.

Edwards, D.C., D.O. Conover and F. Sutter. - 1982. Mobile predators and the structure of marine intertidal communities. Ecology, 63: 1175-1180.

Evans, S.M., P.M. Evans and T. Leksono. - 1996. Widespread recovery of dogwhelks, Nucella lapillus (L.), from tributyltin contamination in the North sea and Clyde sea. Mar. Pol. Bull., 32(3): 263-269.

Fraschetti, S., A. Terlizzi and L. Benedetti-Cecchi. - 2005. Patterns of distribution of marine assemblages from rocky shores: evidence of relevant scales of variation. Mar. Ecol. Prog. Ser., 
296: 13-29.

Hawkins, S.J., H.B.S.M. Corte-Real, F.G. Pannacciulli, L.C. Weber and J.D.D. Bishop. - 2000. Thoughts on the ecology and evolution of the intertidal biota of the Azores and other Atlantic islands. Hydrobiologia, 440: 3-17.

Lawson, G.W. and T.A. Norton. - 1971. Some observations on littoral and sublittoral zonation at Tenerife (Canary Islands). Bot Mar., 14: 116-120.

Levin, S.A. - 1992. The problem of pattern and scale in ecology: the Robert H. MacArthur award lecture. Ecology, 73: 1943-1967.

Liu, L.L., D.W. Foltz and W.B. Stickle. - 1991. Genetic population structure of the southern oyster drill Stramonita (=Thais) haemastoma. Mar. Biol., 111: 71-79.

Martínez-González, M.A., J. De Irala and F.J. Faulín. - 2001. Bioestadística Amigable. Díaz de Santos, Madrid.

McArthur, R.H. and E.O Wilson. - 1967. The theory of island biogeography. Princenton Univ. Press, New Jersey.

Mckillup, S.C. and A.J. Butler. - 1983. The measurement of hunger as a relative estimate of food available to populations of Nassarius paupe. Oecologia, 56: 16-22.

Mckillup, S.C. and R.V. Mckillup. - 1997. Effect of food supplementation on the growth of an intertidal scavenger. Mar. Ecol. Prog. Ser., 148: 109-114.

Menge, B.A. - 1978. Predation intensity in a rocky intertidal community. Oecologia, 34: 1-16.

Menge, B.A., E.L. Berlow, C.A. Blanchette, S.A. Navarrete and S.B. Yamada. - 1994. The keystone species concept: variation in interaction strength in a rocky intertidal habitat. Ecol. Monogr., 64: 249-286.

Moran, M.J. - 1985. Distribution and dispersion of the predatory intertidal gastropod Morula marginalba. Mar. Ecol. Prog. Ser., 22: 41-52.

Moreno, C.A. - 2001. Community patterns generated by human harvesting on Chilean shores: a review. Aquatic. Conserv: Mar. Freshw. Ecosyst., 11: 19-30.

Moro, L. and R. Herrera. - 2000. Las lapas, un recurso en extinción. Medio Ambiente Canarias, 16: 3.

Navarro, P.G., R. Ramírez, F. Tuya, C. Fernández-Gil, P. SánchezJerez and R.J. Haroun. - 2005. Hierarchical analysis of spatial distribution patterns of patellid limpets in the Canary Islands. $J$. Molluscan Stud., 71: 67-73.

Nuñez, J. - 1995. Estudio ecológico del mejillón y otros moluscos en la isla de Fuerteventura. Univ. de La Laguna, La Laguna.

Nuñez, J., M.C. Brito, R. Riera, J.R. Doctito and O. Monterroso. 2003. Distribución actual de las poblaciones de Patella candei D'Orbigny, 1840 (Mollusca, Gastropoda) en las Islas Canarias. Una especie en peligro de extinción. Bol. Inst. Esp. Oceanogr., 19: 371-377.

Ota, N. and M. Tokeshi. - 2000. A comparative study of feeding and growth in two coexisting species of carnivorous gastropods. Mar. Biol., 136: 101-114.
Ramírez, R., F. Tuya, P. Sánchez-Jerez, C. Fernández-Gil, O. Bergasa, R.J. Haroun and J.J. Hernández-Brito. - 2005. Population structure and spatial distribution of the gastropod molluscs $O s i$ linus atrata and Osilinus sauciatus in the rocky intertidal zone of the Canary Islands. Cienc. Mar., 31: 697-706.

Ramírez, R., F. Tuya and R. Haroun. - 2008. El intermareal canario. Poblaciones de lapas, burgados y cañadillas. Univ. de Las Palmas de Gran Canaria, Las Palmas de Gran Canaria.

Richardson, T.D. and K.M. Brown. - 1990. Wave exposure and prey size selection in an intertidal. J. Exp. Mar. Biol. Ecol., 142: $105-120$.

Rilov, G., A. Gasith, S.M. Evans and Y. Benayahu. - 2000. Unregulated use of TBT-based antifouling paints in Israel (eastern Mediterranenan): high contamination and imposex levels in two species of marine gastropods. Mar. Ecol. Prog. Ser., 192: 229-238.

Rilov, G., Y. Benayahu and A. Gasith. - 2001. Low abundance and skewed population structure of the whelk Stramonita haemastoma along the Israeli Mediterranean coast. Mar. Ecol. Prog. Ser., 218: 189-202.

Rilov G., A. Gasith and Y. Benayahu. - 2002. Effect of an exotic prey on the feeding pattern of a predatory snail. Mar. Environ. Res., 54: 85-98.

Rilov, G., Y. Benayahu and A. Gasith. - 2004. Life on the edge: do biomechanical and behavioural adaptations to wave-exposure correlate with habitat partitioning in predatory whelks. Mar. Ecol. Prog. Ser., 282: 193-204.

Rilov, G., A. Gasith, Y. Benayahu. - 2005. Effect of disturbance on foraging: whelk activity on wave-exposed rocky shores with minimal tidal range. Mar. Biol., 147: 421-428.

Stephenson, T.A. and A. Stephenson. - 1949. The universal features of zonation between tide-marks on rocky coasts. J. Ecol., 37: 289-305.

Spence, S.K., S.J. Hawkins and R.S. Santos. - 1990. The mollusc Thais haemastoma- an exhibitor of "Imposex" and potential biological indicator of tributyltin pollution. Mar. Ecol., 11: 147-156.

Thompson, R.C., T.P. Crowe and S.J. Hawkins. - 2002. Rocky intertidal communities: past environmental changes, present status and predictions for the next 25 years. Environ. Conserv., 29: 168-191.

Underwood, A.J. and M.G. Chapman. - 1996. Scales of spatial patterns of distribution on intertidal invertebrates. Oecologia, 107: 212-224.

Underwood, A.J. - 1997. Experiments in ecology: their logical design and interpretation using analysis of variance. Cambridge Univ. Press, Cambridge.

Scient. ed.: M. Ramón.

Received November 30, 2007. Accepted October 20, 2008.

Published online April 6, 2009. 